\title{
Occupational Health Hazards of Farm Woman Engaged in Mango and Cashew Nut Orchards
}

\author{
Gayatri Moharana*, Naresh Babu, Chaitrali S. Mhatre, P. K. Rout and R. S. Panda
}

ICAR-Central Institute for Women in Agriculture, Bhubaneswar, India

*Corresponding author

\begin{abstract}
A B S T R A C T
In fruit crops, women's participations are substantial and their roles are more or less passive. They follow traditional practices and perform various activities with traditional tools are drudgery prone and often lead to occupational health hazards. Women farmers have less awareness and knowledge of tools/ equipment for various unit farm operations. Sometimes if known, the tools and implements are not suitable for them resulting their working efficiency is less and productivity is low. Apart from these working with awkward postures for long hours affect health and induces musculoskeletal problems due to postural discomforts. Keeping these in view, a study was conducted to determine the problems responsible for occupational hazards of the women farmers working in the mango and cashew nut orchards of Dhenkanal district in Odisha. Data were collected from 120 respondents (75 women and 45 men). Group discussion \& interviews were conducted in participatory mode and musculoskeletal problems were identified with Body map. The data revealed that farm workers performed 44 types of activities in mango and cashew nut orchards. Out of the total activities, independent participation of farm women were found in 20 activities whereas the men workers participated in 13 activities independently and participation of both was found in 10 different types of activities. They performed these activities manually or with traditional tools and there were evidences of injuries in hands, palms, fingers \& nails as most of the tasks executed in bare hands. The farmers/ farm women working in orchards or nurseries of Mango and Cashew nut are very less exposed to different manually and power operated tools and equipment used in fruit crops and still they are using the traditional tools. They perform various tasks with static awkward posture and repetitive motion of upper and lower limbs which was responsible for musculoskeletal injuries and disorders in the long run. Hence, there is a need to introduce women friendly farm tools and equipment and protective clothing for the farm women engaged in mango and cashew nut orchards for reducing occupational hazards.
\end{abstract}

\section{Keywords}

Mango and Cashew Nut Orchards, Occupational Health Hazards

\section{Article Info}

Accepted:

26 August 2020

Available Online:

10 September 2020

\section{Introduction}

Farm women are the main stake holder who will lead the agricultural and horticultural activities in our country. Production demands number of activities where a mass of agricultural labourers engaged themselves as their primary occupation. A farm woman suffers a lot of drudgery while performing farming operations and household activities. 
The constraints in agricultural mechanization are due small size of holdings, undulating topography, poor financial conditions of farmer's illiteracy, less awareness about improved implements lack of repair facility in rural areas. It is more evident in the horticultural sector especially in case of the fruit crops. It has been observed that women are generally employed in the operations which are either not mechanized or least mechanized and involve a lot of drudgery. During the activities they adapt unnatural body posture due to which their physiological workload increases and also they faces many types of musculoskeletal problems as a result the efficiency of women to work decreases to a greater extent. Another major factor is that most of the farm tools and equipments for various agricultural operations have been designed mostly for men workers although women are actively engaged in almost all farming activities for long hours in Indian agriculture. Therefore farm women should get more suitable tools\& according to their necessity for performing different activities in agriculture and allied sectors. There are different tools and equipment available for the farmer engaged in horticultural activities related to fruit crops. Most of the equipment designed suitable for man not for farm women and specific to mango \& cashew nut. These tools and equipments are also not available throughout different states. A few ergonomic studies were carried out in this specific area. Focus was also not given to the workers in the orchards in India. The quality of planting material, fruit products, etc. depends on the quality of the production through different stages. Women play a major role in as planting, nursery raising, plant protection activities, quality fruit harvesting to consumer is important to maintaining economic processing operations. It has been realized that tools and equipments should be introduced with women perspective which may largely used by the farm women in future. In order achieve increase production, minimize harvesting loss and getting quality fruits, different manually operated tools and equipment should be introduced among the farm women and men engaged in different activities.

\section{Materials and Methods}

In Odisha, as per the availability of secondary data, Dhenkanal district is considered as the hub for mango and cashew nut in the state. According to the maximum production of Mango and cashew in the state, this district is purposefully selected for the locale of the study where both men and women farmers involve in different activities related to these fruit crops. Hence three orchards from Dhenkanal districts were selected carefully where women's participation in the orchard were clearly visible. Visits were made and established rapport to identify different orchards and nursery for carry out the research prior to data collection to ensure full confidence and co-operation of the respondents. Structured interview schedule were prepared for the data collection from farmwomen and men to identify the extent of participation in activities related to different fruit crops. These schedules were developed as per interaction with the farmwomen regarding their involvement in different activities, drudgery they face while working and awareness about occupational health hazard. Then it was pre-tested and finalized. Survey was conducted in different orchards and discussion \& interviews were conducted in participatory mode. Data on general information about orchards, work profile of respondents, activities performed by the orchard workers, existing use of tools and equipment, were collected by taking into consideration of the major activities carried out in the mango and cashew nut orchards. Data were collected through Supervisors of the selected orchards and collected data were 
cross-checked also. Data for comprehensive schedule of respondents was filled by the identified enumerators. Data were collected covering 120 respondents (women and men). A part from these Body map was used to identify discomfort or pain perceived by the farm women \& men and musculoskeletal problems reported by them respectively.

\section{Results and Discussion}

\section{Participation of farm women and men in mango and cashew nut orchards}

It was found that farm workers performed 44 types of activities in mango and cashew nut orchards. Out of the total activities, independent participation of farm women was found in 20 activities whereas the men workers participated in 13 activities independently and participation of both was found in 10 different types of activities.

All of the men workers involved in land preparation, ploughing, clod breaking, preparation of layout and bed, preparation of soil mixtures, preparation \& application of pesticides, grafting, cutting of grafting layer, pruning, cutting of scion sticks and marketing the harvest whereas women participated in activities related nursery raising, nutrient management, harvest and post harvest activities independently, as well as with men workers. Most of the farm women engaged in the orchards reported that filling of poly bags, removal of shoots and lifting \& shifting of poly bags, weeding, application of fertilizer, manual irrigation, filling of caps were identified as most drudgery prone activities. They performed these activities manually or with traditional tools and there were evidences of injuries in hands, palms, fingers $\&$ nails as most of the tasks executed in bare hands. In case of men, bed preparation \& pit digging, cutting of scion sticks by climbing on mother plants, grafting of mango \& cashew nut plants with bare palm, preparation and application pesticides without any protective measures, preparation of soil mixtures and breaking of clod by bending for hours with awkward postures were to be found very drudgery and hazard prone activities performed by the men workers. The farmers/ farm women working in orchards or nurseries of Mango and Cashew nut are very less exposed to different manually and power operated tools and equipment used in fruit crops. Still they are using the traditional tools and equipment which were very old and rejected by men workers and also not suitable to them.

It was also observed that there was no role $\&$ responsibility of women in the orchards in decision making process as they were controlled by the higher authorities of the orchards. All decisions have been taken by the managers or supervisors. Women are not having any specific responsibilities. Skill workers give their opinion while selecting/ purchasing small tools fertilizers and pesticides, grafting, scion cutting and pruning (Table 2).

Problems related to occupational health hazards of farm women engaged in mango \& cashew nut orchards

Occupational health hazard refers to the potential risks to health and safety for those who work outside and inside the home. As farm women involve both in household and farm activities, they are more prone to this. They are exposed both outdoor and indoor environment. According to the World Health Organization Committee on Occupational Health in 1950, occupational health should aim at the promotion and maintenance of the highest degree of physical, mental and social well-being of workers in all occupations; the prevention among workers of departures from health caused by their working conditions; the 
protection of workers in their employment from risks resulting from factors adverse to health, the placing and maintenance of the worker in an occupational environment adapted to his physiological and psychological equipment, and, to summarize, the adaptation of work to man and of each man to his job.

An attempt was made to identify different types of hazards associated with occupational health of women and men farmers working at the mango and cashew nut orchards. Various types of hazards such as mechanical hazards, chemical hazards, ergonomic hazards, environmental hazards and psycho-social hazards were observed while collecting data from the workers. The major risk factors responsible for hazards are working in awkward postures/ positions, prolonged sitting and standing, squatting, bending, reaching, stretching, heavy /awkward lifting, lifting in combination with twisting, pushing, pulling, carrying, repetition of activities and also due to accidents, slips, trips, falls, lack of knowledge and operating skills about improved tools and implements, lack of protective equipment etc. The prevalence of occupational health hazards in orchards were given in following Table 1.

\section{Musculoskeletal pain of farm workers working in the orchards}

Among different activities carried out by farm women, filling of soil mixtures in poly bags, plantation, clipping of shoots weeding and application of fertilizer were perceived to be very tedious, and hazard prone. In case of cashew nut the liquid secreted from the plant is harmful for skin and causes lesions and patches in the palm. Average percentage of time spending in squatting during the working period was $5 \mathrm{hrs} /$ day. Working continuously for more than $3 \mathrm{hrs}$ in awkward static postures with repetitive movements of upper and lower limbs while filling of soil mixtures in poly bags, planting, weeding, clipping of shoots weeding and application of fertilizer were responsible for inducing drudgery as well as musculoskeletal pain in different parts of the body.

The men respondent perceived grafting and cutting the layer of grafting as the most drudgery prone activities as they adopt static squatting posture for more than hours with repetitive movements of upper \& lower limbs. Preparation of nursery (56\%) was considered the least drudgery prone activity. The static posture such as squatting, bending at lower back or upper back, bending of knee and upper \&lower arm with repetitive movements while performing various tasks by the farm workers including men and women leads to musculoskeletal injuries in the long run. Body map was used to identify discomfort or pain perceived by the farm women $\&$ men and musculoskeletal problems reported by them respectively.

The results obtained from Body Map used for identification of pain in different body parts of the workers revealed that all of the respondents reported having pain in one or more body parts and they have easily located the pain on the map. It was observed that they perform various tasks with static awkward posture and repetitive motion of upper and lower limbs which was responsible for musculoskeletal injuries and disorders in the long run. Out of the total 75 farm woman working in the orchard about 84.5 per cent of them reported pain in lower back, 77.8 per cent of them complained about pain in hip/thighs, 64.5 per cent of them reported pain in both left and right shoulders and the pain was intolerable.

A total of 60 per cent respondents reported pain in both left and right elbow and 53.3 per cent reported pain in both left \& right wrist/ 
hands. About half of them reported pain in mid \& upper back and the pain was moderate. Therefore to reduce musculoskeletal problems, there is a need to introduce women friendly farm tools and equipment and improvement in working posture which will the farm women engaged in mango and cashew nut orchards for reducing drudgery, occupational hazards and encouraging their participation in mango and cashew nut orchards (Fig. 1-3).

Table.1 Types of hazards identified in mango and cashew nut orchards

\begin{tabular}{|c|c|c|}
\hline SI No & Types of hazards & Problems \\
\hline 1. & Mechanical Hazard & $\begin{array}{l}\text { Activities manually or with traditional tools } \\
\text { Injuries in hands, palms, fingers \& nails as most of the tasks } \\
\text { executed in bare hands. } \\
\text { Evidences of using old and trashed tools rejected by men were } \\
\text { used by women. }\end{array}$ \\
\hline 2. & Chemical Hazards & $\begin{array}{l}\text { Preparation and application of fertilizers and pesticides } \\
\text { without any protective measures } \\
\text { Preparation of soil mixtures } \\
\text { Grafting in cashew nut plant(Anacardic acid) } \\
\text { Wiping with lime solution cause itching and burning in palm } \\
\text { Severe allergy and removal of skin of men while grafting } \\
\text { cashew nut plants } \\
\text { Burning eyes } \\
\text { Headache and Nausea }\end{array}$ \\
\hline 3. & Ergonomic hazards & $\begin{array}{l}\text { Prolonged standing, squatting and bending posture. } \\
\text { Awkward postures with repetitive moments of limbs. } \\
\text { Unsuitable farm tools. } \\
\text { Following traditional Methods etc. } \\
\text { Working continuously for more than } 3 \mathrm{hrs} \text { in awkward static } \\
\text { postures with repetitive movements of upper and lower limbs } \\
\text { leads to drudgery. }\end{array}$ \\
\hline 4. & Psycho-social hazards & $\begin{array}{l}\text { Getting lesser wage than men } \\
\text { Dominated/ controlled by the senior staffs. } \\
\text { Lack of training opportunities for employees on proper work } \\
\text { practices. } \\
\text { Lack of basic facilities for women workers in all orchards. } \\
\text { No sick leave. } \\
\text { No wage for absence at work. } \\
\text { Gender differences }\end{array}$ \\
\hline
\end{tabular}


Table. 2 Tools introduced for reducing occupational health hazards and drudgery reduction

\begin{tabular}{|l|l|l|}
\hline SI No & Tools & Activities \\
\hline 1. & Khurpi & Weeding \\
\hline 2. & Hand cultivator & Interculture, weeding \\
\hline $\mathbf{3 .}$ & Up rooter & Uprooting nursery plants \\
\hline $\mathbf{4 .}$ & Hand shovel & Digging, d preparation \\
\hline $\mathbf{5 .}$ & Secateurs & Removing shoots, pruning \\
\hline 6. & Women friendly sprayers & Chemical Application \\
\hline 7. & Masks & Face protection \\
\hline 8. & Gloves & Harvesting cashew nuts, protection of hands, fingers etc. \\
\hline $\mathbf{9 .}$ & $\begin{array}{l}\text { Mango harvester (Dapoli developed Nutan } \\
\text { and Naveen harvester) }\end{array}$ & Harvesting mangoes \\
\hline
\end{tabular}

Fig.1 Percentage involvement of women and men in the orchards

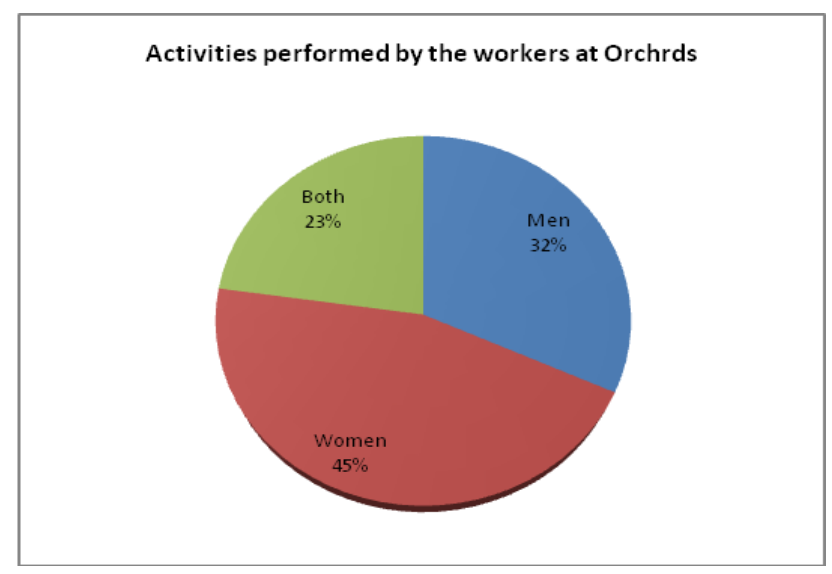

Fig.2 Perceived strain reported by women workers in the orchards

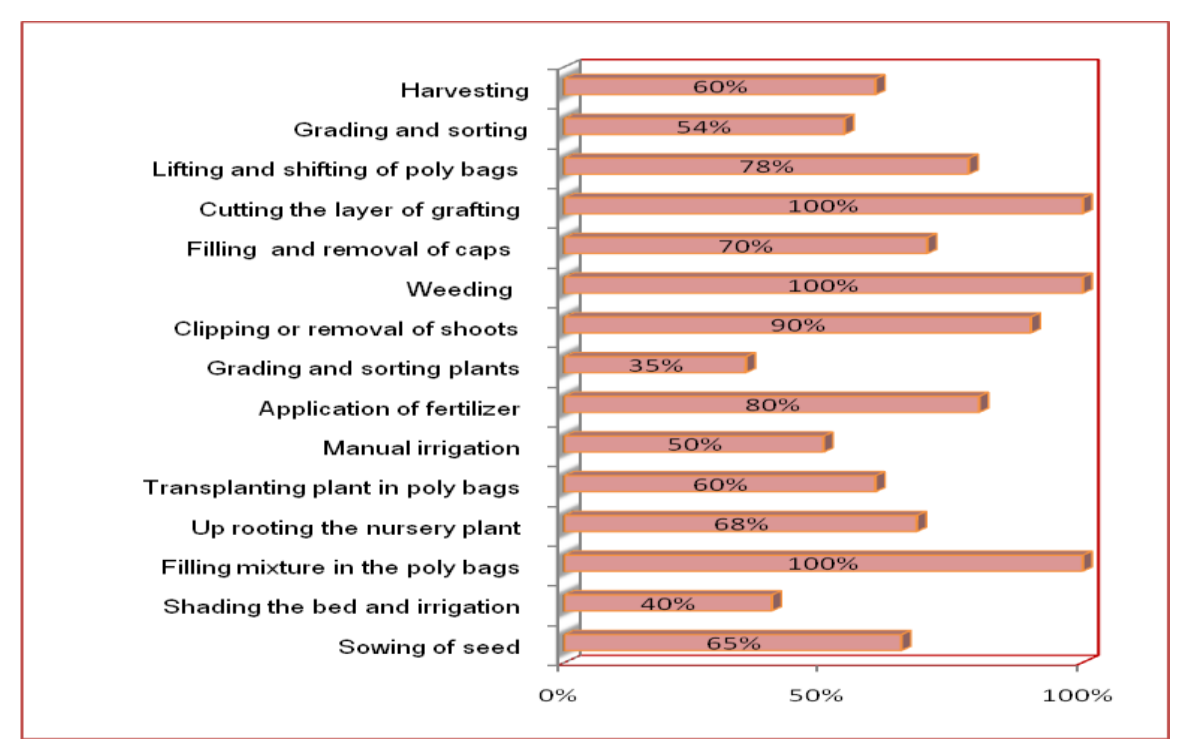


Fig.3 Body Map

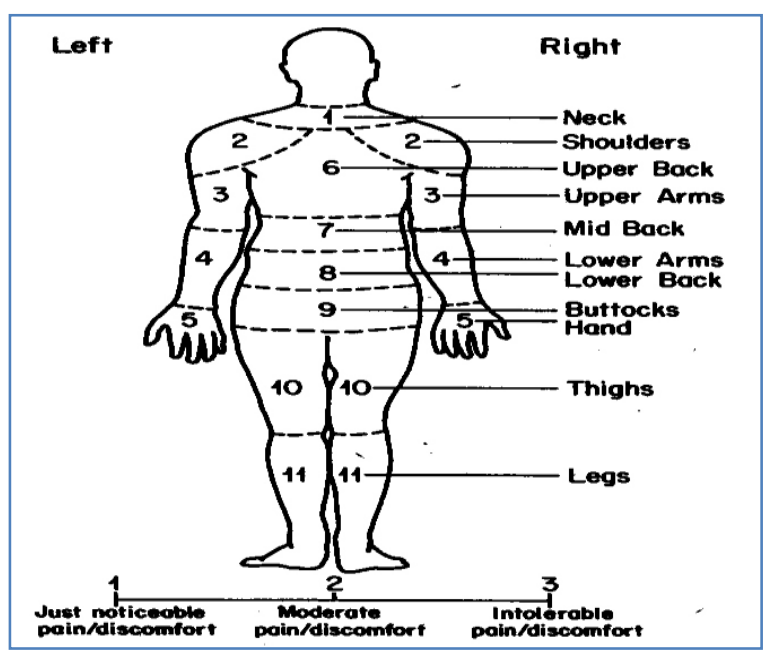

Capacity building programmes for men and women working in the orchards

Farmers-Scientist Interface and stakeholder's meet were organized for capacity building of farm women including men workers in the orchards. Group discussions were conducted for for identification of existing problems and understanding the work contribution of women and use of tools by them in the orchards. Discussed about their work place issues regarding tools and equipment with the owners of orchards for suitable intervention. Capacity building of workers on Work simplification techniques for reducing drudgery was organized at three orchards in Dhenkanal district.

\section{Interventions for reducing occupational health hazards and drudgery reduction}

On the basis of results of present investigation that most of the farm women engaged in the orchards reported that filling of poly bags, removal of shoots and lifting \& shifting of poly bags, weeding, application of fertilizer, manual irrigation, filling of caps were identified as most drudgery prone activities. To reduce occupational health hazards an drudgery selected tools were identified and introduced among men and women workers working in the mango and cashew nut orchards. The information on tools introduced in orchard is given below:

It has been noticed that the workers used the improved tools and implements frequently after interventions. After interventions of khurpi, hand shovel, trowel and secateurs working efficiency increases from 35 to 40 percent.

In conclusion the occupational Health Hazards have been a widespread problem in agriculture in more than a decade. The identification of occupational health hazards and development of systems to evaluate intervene and decrease musculoskeletal risk factors and resulting disorders is quite crucial for safety of farm women. Role of women in horticulture (Fruits cultivation) is increasing day by day can be recognized as an potential in agriculture. There is need to initiate women oriented researches in agriculture. As woman has different ergonomically characteristics than man, design of women friendly tools and equipment is required. Work station should be adjustable to make it comfortable for women 
during performing agricultural activities. Therefore the problems related occupational health of women and men should be identified according to the demand of the job. Various improved tools \& implements and Personal Protective Equipments PPE kits suitable to women farmers can be introduced as interventions which will also men workers. A part from these workplace arrangements can be modified or improved according to the need of the women workers. The issues related to gender gaps can be suitable addressed by the owners of the orchards. Capacity building programme should be organized for repair and maintenance of the tools in regular intervals for updation of their knowledge and skills and improved technologies pertaining to management of orchards to be introduced. More awareness should created for adopting women friendly technologies and provide these tools and implements at the right time to reduce the occupational health hazard of farm women's working in the mango and cashew nut orchards.

\section{References}

Anonymous. 2008. "AICRP on Home Science, Annual Report 2007-2008". Directorate of Research on Women in Agriculture, Bhubaneswar.
Badlissi, F., Dunn, J. E., Felson, D. T. 2005. "Foot musculoskeletal disorders, pain, and foot related functional limitation in older persons". Journal of the American Geriatrics society. 53(6):1029-1033.

Gite, L.P., and Kot, L.S.2003. "Accidents in Indian Agriculture". Technical Bulletin No.CIAE/2003/103, Coordinating Cell, AICRP on Human Engineering and Safety in Agriculture, Central Institute of Agricultural Engineering, Nabibagh, Bhopal.

Hasalkar, S., Budhial, R., Shivalli, R., and Biradar, N. 2004. "Assessment of workload of weeding activity in crop production through heart rate". Journal of Humanecology. 15(3): 165-167.

Kalyani, K.S., Deosingh, K., and Naidu, S.K.2008. "Occupational health Hazards of Farm Women in Tobacco Cultivation". Indian Research Journal of Extension Education 8(1).

Singh, S.P., Singh, R.S., Agarwal, N.2009.

"Women Friendly Improved Farm Tools and Implements for Commercialization". Agricultural Engineering Today. 33(2): 20-25.

Women in Agriculture.2003-04. "DARE/ICAR Annual Report".Pp:173181.

\section{How to cite this article:}

Gayatri Moharana, Naresh Babu, Chaitrali S. Mhatre, P. K. Rout and Panda, R. S. 2020. Occupational Health Hazards of Farm Woman Engaged in Mango and Cashew Nut Orchards. Int.J.Curr.Microbiol.App.Sci. 9(09): 3455-3462. doi: https://doi.org/10.20546/ijcmas.2020.909.429 